\title{
ОСОБЛИВОСТІ РЕГЕНЕРАЦІ РАН У ТВАРИН 3 ЕКСПЕРИМЕНТАЛЬНОЮ ОПІКОВОЮ ТРАВМОЮ ПРИ ПРОВЕДЕННІ РАННЬОГО ХІРУРГІЧНОГО ЛІКУВАННЯ З ВИКОРИСТАННЯМ ГІДРОГЕЛЕВИХ РЕГЕНЕРАТИВНИХ ЗАСОБІВ ТА ГУБЧАСТИХ СОРБУЮЧИХ МАТЕРІАЛІВ
}

\author{
(СА. О. Ковальчук \\ ДВНЗ «Тернопільський державний медичний університет імені І. Я. Горбачевського МОЗ України»

\begin{abstract}
PЕЗЮMЕ: У роботі досліджено особливості регенераці опікових ран у експериментальних тварин при проведенні ранньо некректомі опікового струпа із подальшим закриття ранового дефекту сучасними гідрогелевими пов'язками та сорбуючими губчастими засобами. Експериментально доведено, що застосування гідрогелевих засобів на етапах раннього хірургічного лікування безпородних білих щурів сприяє активному росту грануляційно тканини, послаблює запальну реакцію та забезпечує епітеліогенний ефект.

КЛЮЧОВІ СЛОВА: опіки, некректомія, гідрогелеві засоби, регенерація.
\end{abstract}

Вступ. Для напрямлено корекці репаративно регенераці пошкоджених термічним фактором тканин на сьогоднішній день використовують різноманітні лікарські форми препаратів з різним механізмом ді [1-5]. Результатом неадекватного консервативного лікування опіків може бути розвиток рубцевих деформацій і контрактур у обпечених хворих в періоді реконвалесценці [6]. Оптимізація методик місцевого лікування постраждалих від опіків $\epsilon$ важливим завданням сучасно комбустіологі.

На сьогодні при опікових ураженнях одним із стратегічних підходів до оптимізаці лікування ран вважають забезпечення вологого мікроклімату [7]. За тако умови запобігається надмірне висихання тканин і заглиблення некрозу. У вологому середовищі імунокомпетентні клітини і клітини власне шкіри значно швидше здійснюють міжклітинну взаємодію, екскрецію позаклітинного матриксу та цитокінів, прискорюється проліферація кератиноцитів і ендотеліоцитів [8-11], краще зберігається водний баланс глибоких структур, розташованих під епідермісом [12-14].

Велика увага науковців спрямована на розробку ранових засобів з підсиленою сорбційною спроможністю та покращеними дренажними властивостями. Останнім часом у комбустіологі все частіше застосовують комбіновані ранові покриття, які включають біосинтетичні регенеративні компоненти.

Матеріал і методи дослідження. Експериментальне дослідження проведено на 192 безпородних статевозрілих білих щурах масою 250-300 г. Згідно з європейською конвенцією про гуманне поводження з лабораторними тваринами опік наносили під загальним ефірним наркозом за методикою Regas F. C., Ehrlich H. P. (1992) [15]. Методика виконання експериментально травми передбачала контактний опік III-IV ступенів звільнено від шерсті шкіри спини. Опік наносили мідною пластиною, яку попередньо розігрівали в кип'яче- ній воді при температурі $97-100^{\circ} \mathrm{C}$, а потім щільно прикладали до шкірно поверхні піддослідно тварини впродовж 20 секунд, при цьому площа опіку становила 10-15\% поверхні тіла.

Усіх піддослідних тварин поділили на 3 групи. До складу контрольно групи увійшли 8 здорових тварин. До складу першо групи віднесли 24 тварини з опіковою травмою, лікування яких включало проведення некректомі на 6 добу після травми з подальшим закриттям ран гідрогелевими монопов'язками; до друго групи віднесли 24 тварини, яким проводили раннє хірургічне лікування з використанням гідрогелевих монопов'язок; до третьо групи віднесли 24 тварини, яким проводили раннє хірургічне лікування з використанням сітчастих гідрогелевих пов'язок та поліуретанових адсорбентів.

Після проведення некректомі та закриття ран гідрогелевими та сорбуючими засобами звертали увагу на прозорість первинних пов'язок та наявність виділень під ними, щільність $х$ прилягання до рани, загальний об'єм гелево субстанці. При зміні кольору та помутнінні гелевого субстрату пов'язки на поверхні рани замінювали. Виражене просякання ексудатом вторинних пов'язок також вказувало на потребу х заміни на поверхні первинних пов'язок.

Оцінювали площу опікових ран, визначених попередньо при первинному огляді після експериментально індуковано травми, зіставляли з площею ранових поверхонь обпечених тварин під час лікування. Звертали увагу на стан шкірних покривів та опікових ран, репаративні процеси у ранах, крайову епітелізацію, колір та рельєф грануляційно тканини, характер запальних процесів, зокрема ексудативні явища в ранах тощо.

У тварин I групи після проведено некректомі та гемостазу кровоточивих ділянок (на 6 добу після травми) рани закривали напівпроникним гідрогелевим монопокриттям «Aqua-Gel». Препарат $є$ композицією натуральних і синтетичних полімерів 
Оеляди літератури, оригінальні дослідження, поеляд на проблему

(полівінілпіролідон, поліетиленгліколь) у воді. Для лікування ран у піддослідних тварин II групи застосовували аналогічне гідрогелеве монопокриття.

Тактика лікування ран у піддослідних тварин III групи передбачала використання покриття «SanoSkin-Net» в якості первинно пов'язки, та сорбуючого покриття «SanoSkin-Foam», що використовувалось як вторинна пов'язка. Перев'язувальний матеріал складається із води і акрилових сполук, отриманих в результаті радикально полімеризаці гідрофільних мономерів (акрилово кислоти, полівінілпіролідону). Пов'язка складається з бавовняно-полістиролово сітки, на яку наносять прозорий гель, який може поглинути надлишок ексудату, що в 15 разів перевищує його власну вагу. Пов'язку «SanoSkin-Foam» в якості вторинного покриття накладали на поверхню сітчасто гідрогелево пов'язки. Сорбуюча губка виконана з м'яко дрібнопористо поліуретаново піни і за рахунок ефекту вертикально капілярності забезпечує всмоктування та утримання надлишкових виділень 3 поверхні рани.

Результати й обговорення. Визначення особливостей репаративно регенераці уражених термічним фактором шкірних покривів при проведенні хірургічно некректомі уражених тканин в різні терміни опіково хвороби дає можливість виявити важливі відмінності патогенезу ранового процесу. Такі дослідження є визначальними у процесі формування тактики і стратегі лікування хворих із термічною травмою.

На 6 добу після травми (рис.1) проводили некректомію опікового струпа, після чого рани закривали пов'язками з антисептиками.

Для вирішення поставленого завдання спостереження проводили на 7, 14, 21 добу після експериментально індуковано опіково травми. Вищевказані часові параметри досліджень відповідають II фазі перебігу ранового процесу. Саме в цьому періоді рана виповнюється новоутвореною грануляційною тканиною, яка є важливим матеріалом для дослідження репаративно регенераці в опіковій рані.

У ході експерименту на 7 добу після нанесення опіково травми при об'єктивному огляді ділянки ураження у тварин контрольно групи спостерігалась тьмяна грануляційна тканина $з$ ділянками паранекрозу, набряком підлеглих тканин, вираженою ексудацією з раново поверхні (рис. 2).

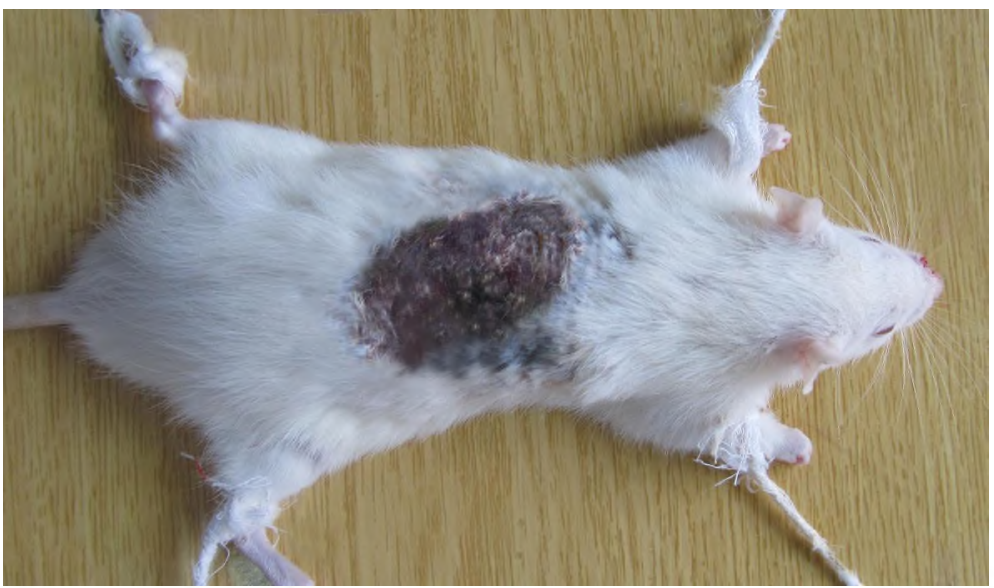

Рис. 1. Ділянка деструкці дерми у піддослідно тварини на 6 добу експерименту. Щільний опіковий струп.

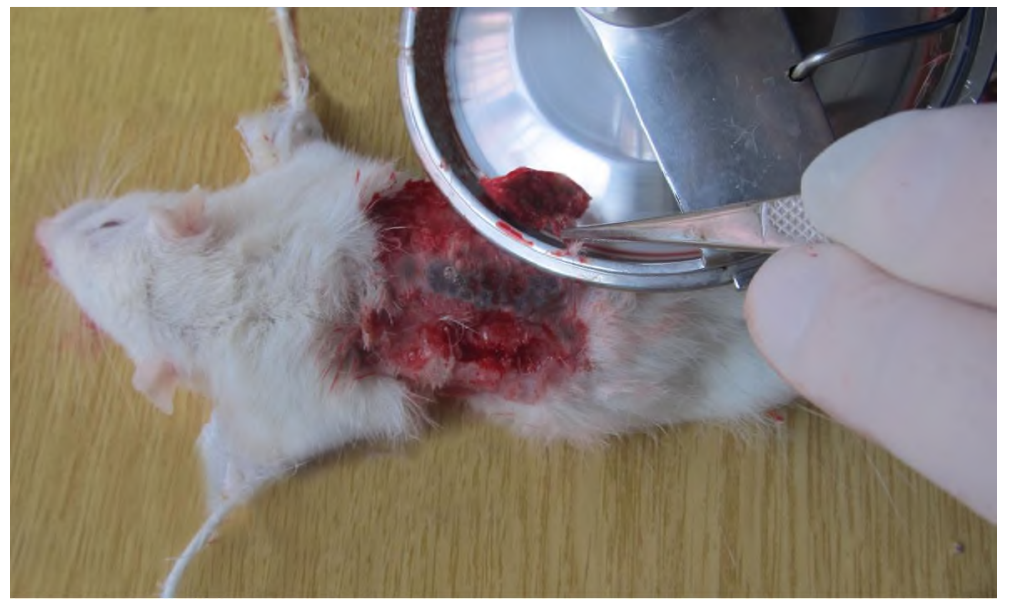

Рис. 2. Дерматомна некректомія уражених тканин у піддослідно тварини на 7 добу експерименту. 
Оеляди літератури, ориеінальні дослідження, поеляд на проблему

Загалом, на 7 добу після нанесення травми, при проведенні традиційного хірургічного лікування в опікових ранах контрольно групи тварин відмічаються залишкові ділянки некротично дерми, пригнічення формування грануляційно тканини, глибока деструкція сполучнотканинних елементів.
Хірургічне лікування із застосуванням гідрогелево пов'язки проводили через 24 години після травми. Для закриття ран використовували лікувальну композицію, що містить натуральні і синтетичні полімери, такі як полівінілпіролідон та поліетиленгліколь. Вказані засоби належать до сучасних гідрогелевих покриттів III покоління (рис. 3).

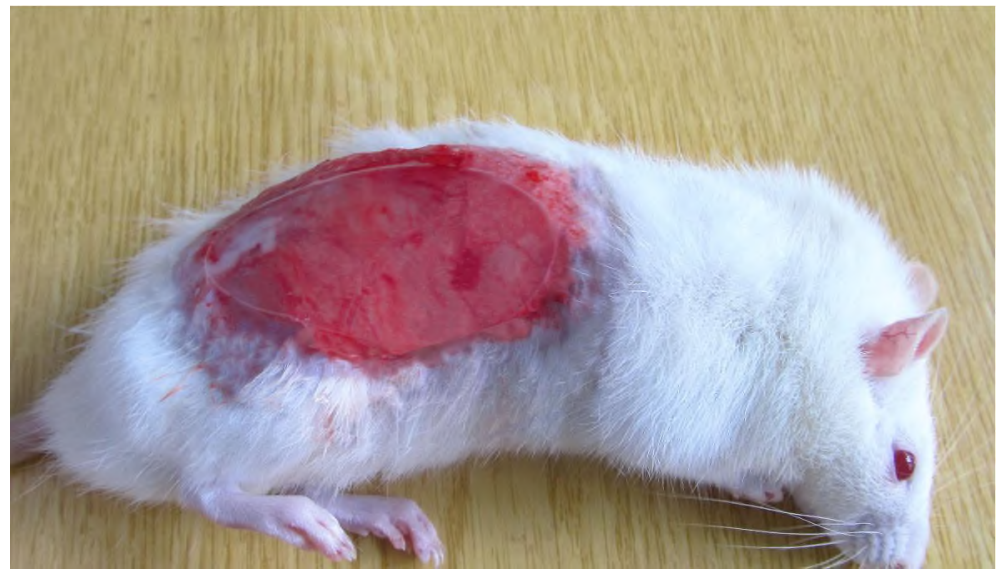

Рис. 3. Фіксоване на рані гідрогелеве покриття (7 доба після травми).

Після обробки операційного поля антисептиками в ділянці опіку III ступеня видаляли некротичні шари дерми за допомогою дискового електродерматома, проводили гемостаз та закривали рани вологозберігаючими покриттями, фіксацію яких здійснювали шляхом контурного бинтування. В подальшому, через кожні 24 години об'єктивно оцінювали стан пов'язки та раново поверхні.

Методика лікування включала заміну гідропов'язки на ранах через кожні 2 доби. Однак у 15 піддослідних щурів II групи впродовж перших двох днів та в 9 тварин ціє ж групи впродовж перших трьох днів через кожні 24 години проводилась додаткова заміна гідропов'язки. При цьому спостерігалось помутніння та втрата прозорості гідрогелево субстанці, що свідчило про повне насичення сорбуючого шару гелю запальним ексудатом. Між рановою поверхнею та гідрогелевою пов'язкою відмічались поодинокі острівцеві скупчення серозно-геморагічних виділень. Вказані ускладнення також розвивались після капілярно кровотечі з поверхні рани, в таких випадках між гідропов'язкою та рановою поверхнею виявляли згустки крові.

Таким чином, використання гідрогелевих ранових покриттів при лікуванні глибоких опіків приводить до зменшення запально реакці та покращення морфологі як новоутворено грануляційно тканини, так і глибоких тканин ушкоджено шкіри. Однак слід визнати, що локальне накопичення виділень під гідрогелевим шаром пов'язки в результаті кровотечі або надмірно серозно-геморагічно ексудаці $\epsilon$ патологічною передумовою для розвитку запальних явищ у післяопераційній рані.
У III групі спостережуваних тварин досліджували ефективність раннього хірургічного лікування із застосуванням гідрогелево композиці, носієм яко $є$ трикотажна бавовняно-полістиролова сітка. Вказаний засіб належить до сучасних гідрогелевих ранових покриттів III покоління. Гідрофільна гелева субстанція препарату включає компоненти полімерів акрилово кислоти.

Як і в попередній групі тварин, некректомію проводили на 2 добу після травми. Важливим етапом операці був адекватний гемостаз. Ділянки капілярно кровоточивості ушивали вузловими швами. Операційне поле промивали розчинами антисептиків та просушували стерильними серветками. На операційній рані після гемостазу фіксували сітчасте гідрогелеве покриття, поверх якого накладали сорбуючу поліуретанову губку (рис. 4,5$)$. В таких умовах при надмірній серозно-геморагічній ексудаці ранові виділення активно дренувалися в основу поліуретанового сорбуючого покриття через отвори сітчасто гідропов'язки. Гелева субстанція сітчастого покриття при адсорбці ранових виділень збільшувалась в об'ємі, при цьому зміна кольору та помутніння гелево маси були показаннями до заміни вказано первинно пов'язки на поверхні ран у 12 тварин III групи через 24 години після операці . Загалом всім тваринам дано групи до 7 дня експерименту з метою активно абсорбці виділень та профілактики накопичення ексудату під первинною пов'язкою через кожні 3 доби проводили заміну як первинного гідрогелевого, так i вторинного поліуретанового покриттів на ранових поверхнях. При цьому гелева субстанція була переважно прозорою, лиш місцями спостерігалось 
Оеляди літератури, оригінальні дослідження, поеляд на проблему незначне помутніння. А на поверхні вторинно пов'язки відмічались ознаки просякання сероз-

но-геморагічним ексудатом, що підтверджувало високу сорбуючу спроможність (рис. 6).

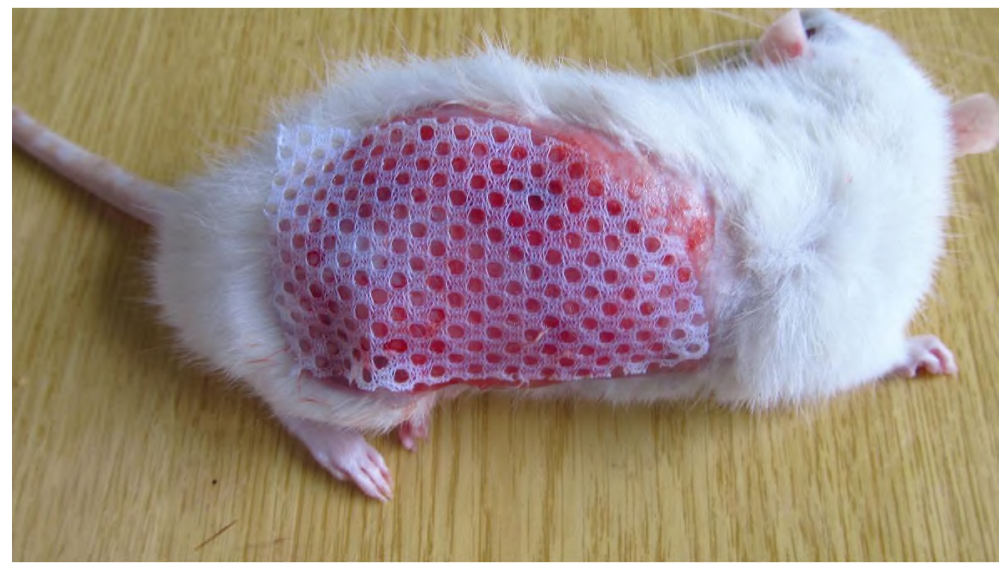

Рис. 4. Фіксоване на рані сітчасте гідрогелеве покриття після проведено некректомі .

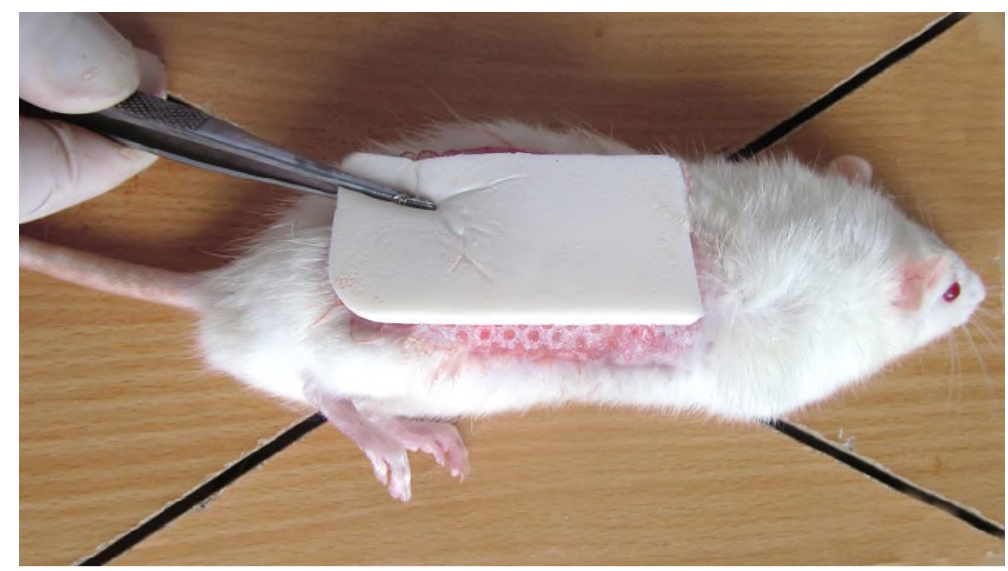

Рис. 5. Фіксація сорбуючо поліуретаново губки на поверхні первинного покриття після проведено некректомі .

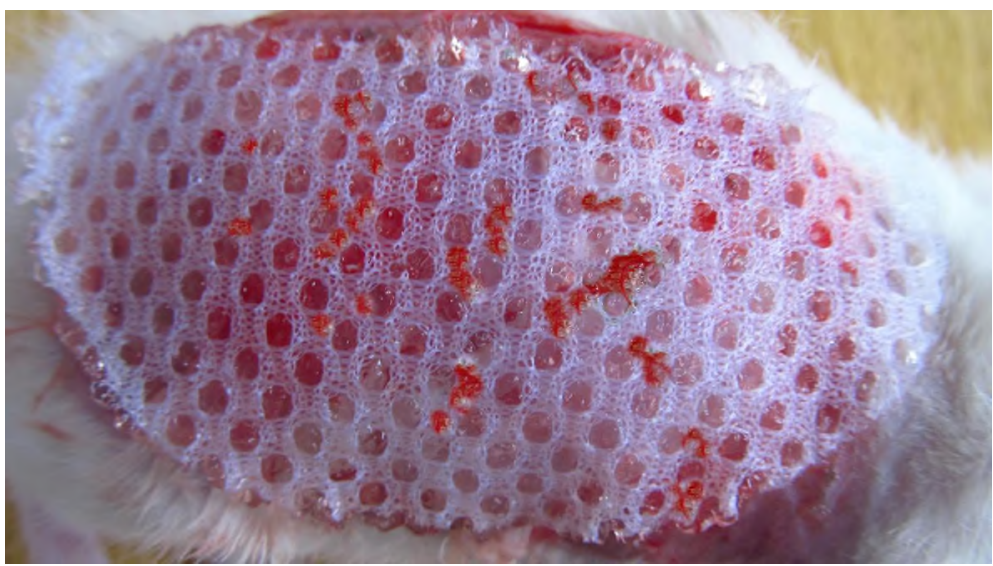

Рис. 6. Збільшена в об'ємі гелева субстанція сітчастого покриття в результаті абсорбці ранового ексудату (третя доба перебування пов'язки на рані).

Використання запропонованого первинного та вторинного покриття приводить до значного покращення морфологі рани та прилеглих шарів шкіри експериментальних тванин. Спостерігається активне формування грануляційно тканини при відсутності гнійного запалення. Запальний інфільтрат проникає в прилеглі тканини, проте вира- женість інфільтраці $\epsilon$ меншою, порівняно 3 попередніми групами.

На 14 добу після нанесення опіково травми при проведенні традиційного лікування на поверхні гранулюючих ран виражена серозно-гнійна ексудація. Місцями грануляці в'ялі з блискучою поверхнею (рис. 7). 


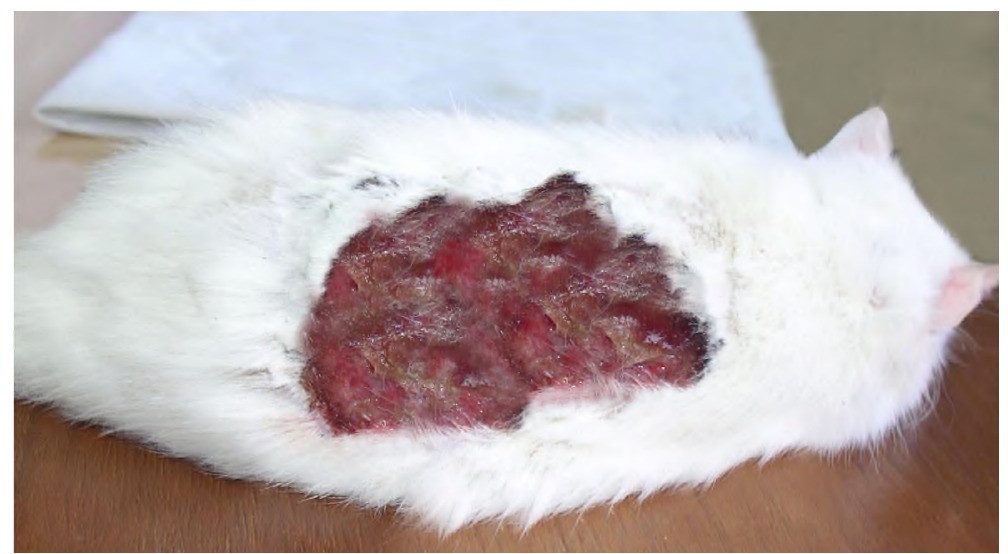

Рис. 7. Опіковий струп з ділянкою гнійного запалення (14 доба після травми).

Ушкоджена ділянка шкіри вкрита грануляційною тканиною з розвинутою судиною сіткою.

В крайових зонах рани на поверхні грануляцій відбувається утворення острівців епітелізаці, джерелом яко $є$ збережені тканини та придатки шкіри, проте площа епітелію є незначною. Уповільнення процесів епітелізаці рани $є$ наслідком високо запально активності та порушення процесів кровопостачання регенерату. Проте ріст епітелію свідчить про початок фази епітелізаці регенерату.

Використання гідрогелевих монозасобів для закриття опікового дефекту приводить до оптимізаці процесів регенераці шкіри.

Так, на 14 добу після травми гідропов'язки фіксовані на ранах, однак місцями спостерігаются ділянки х вираженого помутніння в проекці осередків серозно-гнійних виділень. Гідрогелевий субстрат легко видаляється з поверхні ран без травматизаці молодого регенерату. По перифері ран виражена крайова епітелізація, по центру також острівцевий епітелізат.

На поверхні грануляцій відбувається формування епітеліального шару, ріст якого відбувається від крайових зон до центру дефекту (рис. 8).
За умов застосування сітчастого гідрогелевого покриття та сорбуючо поліуретаново губки відбувається утворення оптимального мікросередовища на поверхні рани, що забезпечує прискорення регенераці опіково ділянки. Після видалення сорбуючо губки відмічається повноцінна фіксація гідрогелевого покриття на рановій поверхні без виражених ознак помутніння та зміни кольору гелево субстанці, при цьому гнійні виділення відсутні (рис. 9).

Таким чином, застосування сітчастого гідрогелевого покриття в комбінаці з сорбуючою поліуретановою губкою приводить до оптимізаці мікрооточення поверхні рани, що веде до зменшення інфільтраці, активізаці васкулогенезу та епітелізаці поверхні грануляційно тканини.

Через 21 добу після нанесення опіку в рані тварин, яких лікували традиційним методом, на поверхні ран грануляційна тканина тьмяно-рожевого кольору, з залишковими явищами серозногнійно ексудаці (рис. 10).

У периферійних ділянках рани на поверхні грануляційно тканини утворюється шар епітеліально тканини. При цьому товщина епітелію є незначною, що свідчить про сповільнений процес епітелізаці .

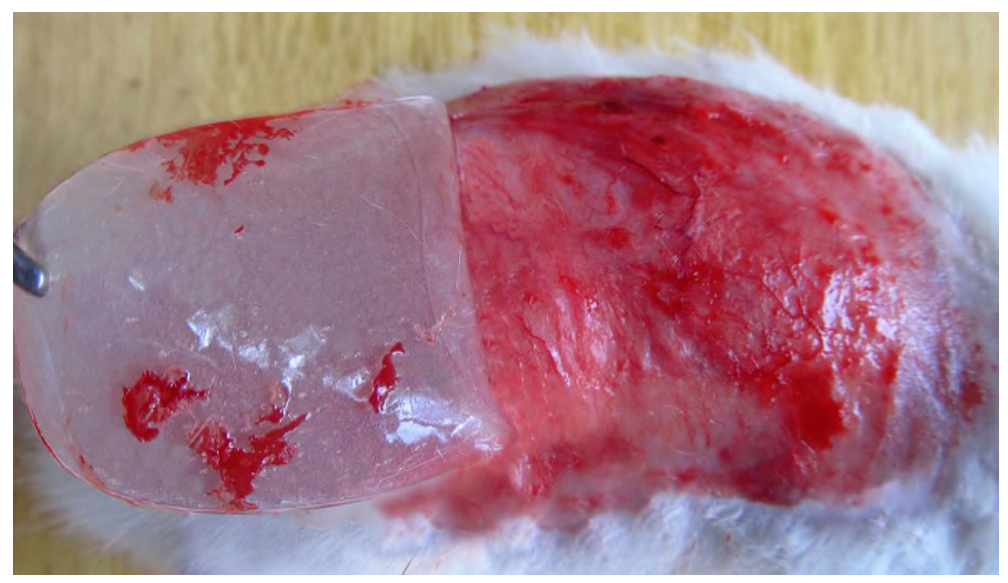

Рис. 8. Ділянка грануляційно тканини під видаленою гідрогелевою монопов'язкою (14 доба після травми). 
Оеляди літератури, ориаінальні дослідження, поеляд на проблему

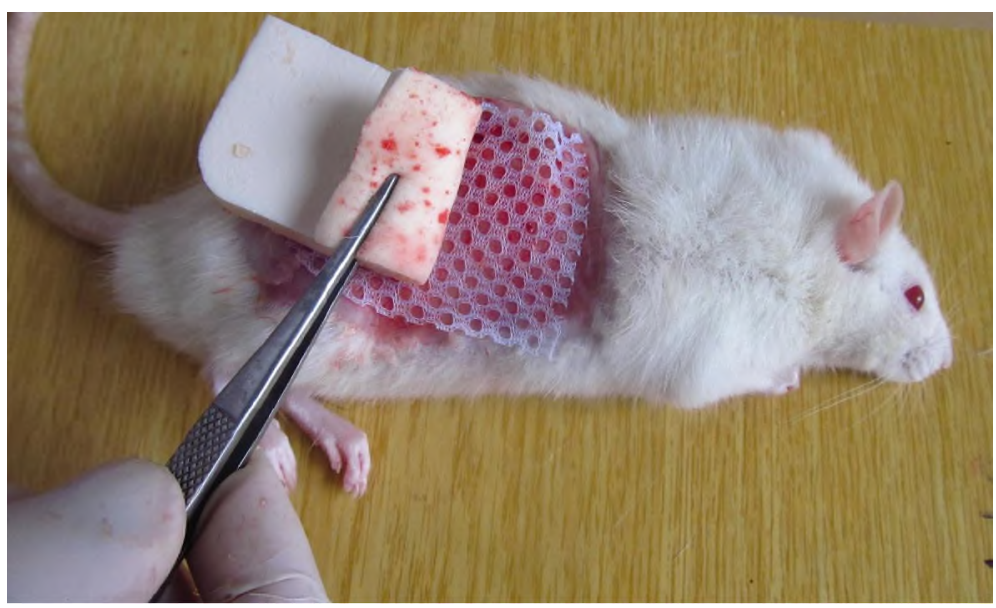

Рис. 9. Просякнуте рановим ексудатом поліуретанове покриття після відшарування з поверхні сітчастого гідрогелевого покриття (14 доба після травми).

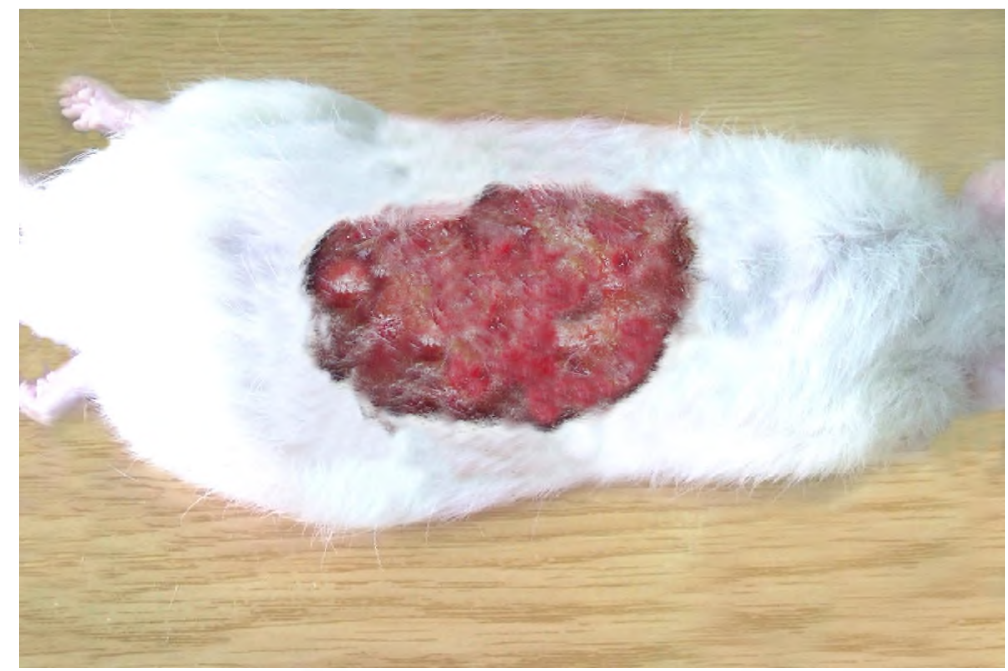

Рис. 10. Гранулююча рана з ділянками гнійного запалення при проведенні традиційного лікування (21 доба після травми).

Застосування для закриття дефекту гідрогелево монопов'язки приводить до оптимізаці репаративних процесів в опіковій рані. Після видалення ранового покриття на 21 добу спостерігається активна крайова епітелізація, геометричні розміри ран зменшуються на $(21,0 \pm 4,6) \%(p<0,1)$. Ознаки гнійно ексудаці в ділянках видалення гідропов'язки виражені в меншій мірі, порівняно з 14 добою спостереження. Грануляційна тканина рожевого кольору, з ділянками капілярно кровоточивості (рис. 11).

При використанні сітчасто гідрогелево пов'язки та сорбуючого поліуретанового покриття для закриття опіково травми виявлена найбільш повна регенерація рани. Через 21 день після термічно травми рановий дефект вистелений грануляціями рожевого кольору, що незначно кровоточить. В результаті активно крайово епітелізаці загальна площа ран зменшується на $(32,0 \pm 5,4) \%$ (рис. 12).
Нормалізація кровопостачання рани та створення оптимального мікрооточення під поверхнею сітчасто гідропов'язки приводить до повно епітелізаці периферійних ділянок рани.

Висновки. У ході експерименту виявлена висока регенераторна спроможність гідрогелево пов'язки з додатковим сорбуючим шаром. На всіх термінах експериментального дослідження спостерігалась повна фіксація сітчастого гідропокриття на рановій поверхні без явищ відшарування та лізису.

Перфорована структура первинно пов'язки та висока сорбуюча здатність поліуретаново губки забезпечує активний дренаж ексудату, а відтак створює оптимальні умови для місцево-лікувально ді регенеративного субстрату, що, в свою чергу, проявляється зменшенням набряку підлеглих тканин, нормалізацією кровообігу та більш повноцінним відновленням структури уражено дерми. 


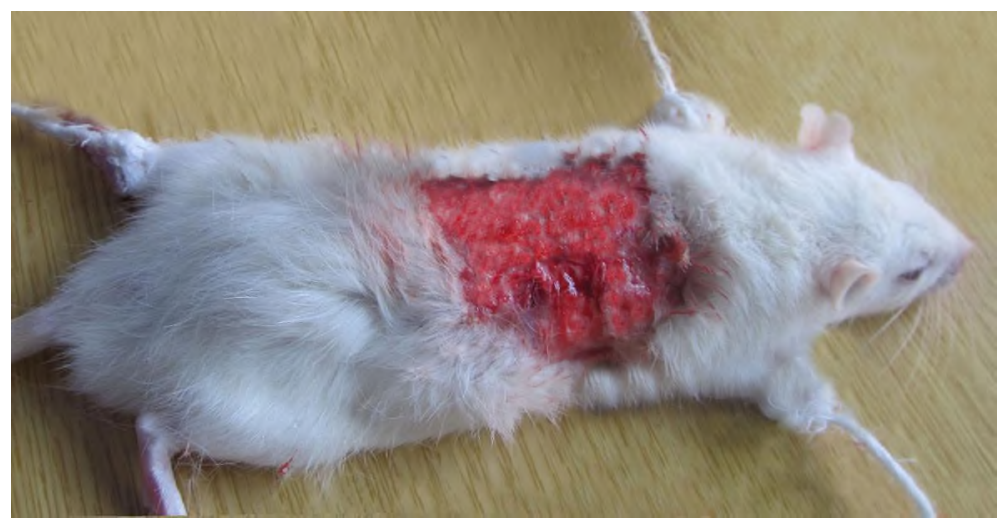

Рис. 11. Гранулююча рана під видаленою гідрогелевою монопов'язкою (21 доба після травми).

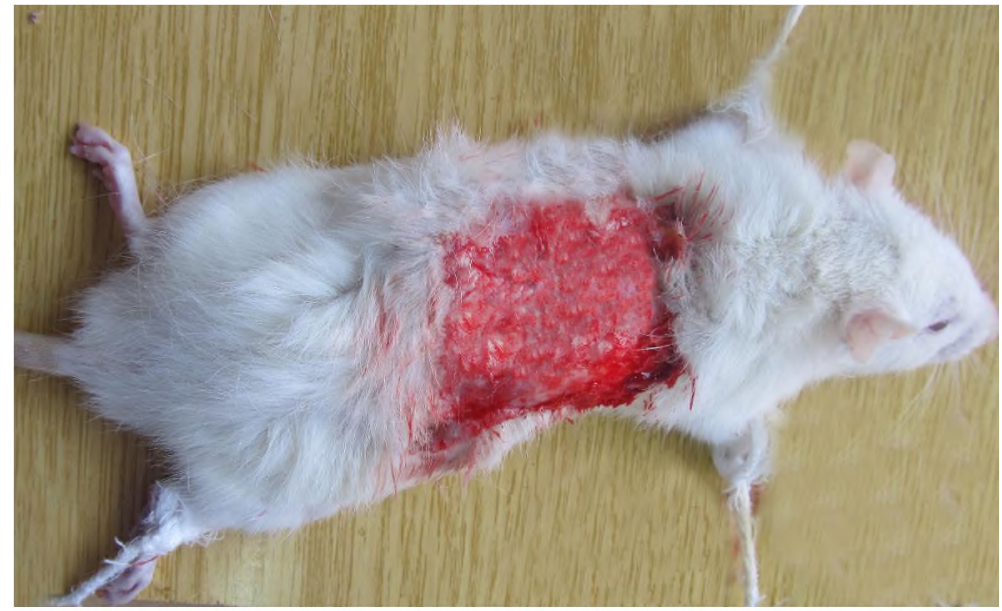

Рис. 12. Гранулююча рана під видаленою сітчастою гідрогелевою пов'язкою та сорбуючою губкою (21 доба після травми).

Комбіноване використання вторинного сорбуючого поліуретанового покриття та сітчастих гідрогелевих засобів сприяє активному дренажу виділень при надмірній ексудаці, а відтак забезпечує адекватну санацію вогнищ інфікування уражених тканин.

Таким чином закриття опікових ран комбінованою композицією гідрогелевого покриття та

\section{ЛITЕРАТУРА}

1. Современные раневые покрытия в местном лечении ран различного генеза / Д. В. Шаблин, С. Г. Павленко, А. А. Евглевский, [и др.] // Фундаментальные исследования. - 2013. - № 12 (часть 2). - С. 361-365.

2. Добыш С. В. Современные перевязочные средства для лечения ран во второй фазе раневого процесса / С. В. Добыш, А. В. Васильев, О. В. Шурупова // Материалы Международной конференции / под ред. В. Д. Федорова, А. А. Адамяна. - М., 2001. - С. 115.

3. Современные тенденции в создании биологически активныхматериаловдля лечения гнойныхран/Н. А. Ефименко, Ф. Е. Шин, М. П. Толстых, А. С. Тепляшин // Воен. мед. журн. - 2002. - Т. 323, № 1. - С. 48-52.

4. Андреев Д. Ю. Современные раневые покрытия. Ч. І / Д. Ю. Андреев, Б. А. Парамонов, А. М. Мухтарова // поліуретаново губки сприяє активному росту грануляційно тканини, послаблює запальну реакцію та забезпечує епітеліогенний ефект.

Перспективи подальших досліджень. У подальшому плануємо вивчати динаміку мікробно контамінаці ран у групах спостережуваних тварин.

Вестн. хирургии им. И. И. Грекова. - 2009. - Т. 168, № 3. C. $98-102$.

5. Адамян А. А. Современные биологически активные перевязочные средства в комплексном лечении ран // Материалы 4 Международной конференции / под ред. В. Д. Федорова и А. А. Адамяна. - М., 2001. С. $25-27$.

6. Козинець Г. П. Опікова хвороба / Г. П. Козинець, О. Н. Коваленко, С.В. Слесаренко // Мистецтво лікування. -2006 . - № 12. - С. 9-15.

7. Эффективность новых гидроколлоидных раневых покрытий в лечении трофических язв нижних конечностей / Д. Ю. Андреев, В. М. Седов, С. Ф. Антонов, Б. А. Парамонов // Материалы XI съезда хирургов Российской Федерации. - 2011. - С. 27-29. 
Оеляди літератури, оригінальні дослідження, поеляд на проблему

8. Use of gene-modified keratinocytes and fibroblasts to enhance regeneration in a full skin defect / J. A. Lohmeyer, F. Liu, S. Krbger [et al.] // Langenbecks Arch Surg. - 2011. Vol. 2, № 3. - P. 76-79.

9. Hydrogen peroxide resolves neutrophilic inflammation in a model of antigen-induced arthritis in mice / F. Lopes, F. M. Coelho, V. V. Costa [et al.] // Arthritis Rheum. - 2011. Vol.10, № 2. - P. 169-172.

10. Opasanon S. Clinical effectiveness of alginate silver dressing in outpatient management of partial-thickness burns / S. Opasanon, P. Muangman, N. Namviriyachote // Int. Wound J. - 2010. - Vol. 7, № 6. - P. 467-471.

11. Park J. B. Healing of extraction socket grafted with deproteinized bovine bone and acellular dermal matrix: histomorphometric evaluation / J. B. Park // Implant Dent. -
2010. - Vol. 19, № 4. - P. 307-313.

12. Dermal substitution with Matriderm in burns $/ \mathrm{H}$. Ryssel, G. Germann, O. Kloeters [et al.] // Burns. -2010. - Vol. 25, № 4. - P. 567.

13. A review of the local pathophysiologic bases of burn wound progression / J. W. Shupp, T. J. Nasabzadeh, D. S. Rosenthal, [et al.] // J. Burn. Care Res. - 2010. - Vol. 31, № 6. - P. 849-873.

14. Verified centers, nonverified centers, or other facilities: a national analysis of burn patient treatment location / D. Zonies, C. Mack, B. Kramer [et al.] // J. Am. Coll. Surg. 2010. - Vol. 21, № 3. - P. 299-305.

15. Regas F. C. Elucidating the vascular response to burns with a new rat model / F. C. Regas, H. P. Ehrlich // J. Trauma. - 1992. - Vol. 32, № 5. - P. 557-563.

\title{
FEATURES WOUND HEALING IN ANIMALS WITH EXPERIMENTAL BURN INJURY DURING EARLY SURGICAL TREATMENT USING HYDROGEL REGENERATIVE VEHICLES AND SPONGIFORM SORBENT MATERIAL
}

\author{
(CA. O. Kovalchuk
}

SHEI «Ternopil State Medical University by I.Ya. Horbachevsky of MPH of Ukraine»

SUMMARY. In this paper we investigate the features of regeneration of burn wounds in experimental animals during the early necrectomy eschar followed by closure of the wound defect modern Hydrogel dressings and spongy sorbent means. Experimentally proved that the use of hydrogel funds stages of early surgical treatment outbred albino rats promotes active growth of granulation tissue, reduces the inflammatory response and provides epiteliogenny effect.

KEYWORDS: burns, necrectomy, hydro gel means regeneration.

Отримано 4.02.2015 